\title{
SEXUALLY DIMORPHIC \\ PLUMAGE CHARACTERISTICS IN THE NORTHERN BLACK SWIFT
}

\author{
CAROLYN GUNN, P. O. Box 791, Dolores, Colorado 81323; \\ wolverine1.cg@gmail.com \\ KEVIN J. AAGAARD, Colorado Parks and Wildlife, 317 West Prospect Road, Fort \\ Collins, Colorado 80526 \\ KIM M. POTTER, White River National Forest, Rifle Ranger District, 0094 County \\ Road 244, Rifle, Colorado 81650
}

JASON P. BEASON, SWCA Environmental Consultants, 295 Interlocken Blvd., \#300, Broomfield, Colorado 80021

ABSTRACT: Most published accounts of the Northern Black Swift (Cypseloides niger borealis) contain disagreements and inaccuracies concerning the species' sexual dimorphism in plumage. These reports represent small sample sizes and are not based on birds recaptured and followed over time. In our study, to gain a better understanding of dimorphic plumage characteristics, we captured swifts at four breeding colonies in the Rocky Mountains from 2004 through 2017. We banded breeding adults, recorded eight metrics (wing chord, flat wing, length of the outermost [r5] and innermost [r1] rectrices, the difference in these lengths, length of white tipping on the abdomen and undertail coverts, and weight), and photographed the birds' underparts. We followed these characteristics in birds recaptured for up to 13 years. The difference in the mean depth of the tail fork $(r 5-r 1)$ was the most definitive plumage characteristic distinguishing the sexes of adults, being accurate in 95\% of the birds examined. With few exceptions, males had only slight white tipping of the abdominal feathers and undertail coverts, whereas females had significantly longer white tipping on those feathers. Individuals that were recaptured did not change appreciably over time in wing chord, depth of tail fork, or degree of white tipping on the abdomen and undertail coverts. This is the largest and longest study of sexual dimorphism in the Northern Black Swift and clarifies previous misinterpretations of these characteristics.

Differences between the plumages of adult male and female Northern Black Swifts (Cypseloides niger borealis) have been debated since 1857, when the type specimen was collected at Simiahmoo Bay, Puget Sound, Washington Territory (Kennerly 1857). Starting with this initial description, observers drew varying conclusions about how the plumage varied with sex and age. The purpose of our project was to identify sexually dimorphic plumage characteristics in adult Black Swifts.

Some previous observers concluded, from freshly collected or museum specimens, that adult male and female Black Swifts are indistinguishable by plumage. Drew (1882), Swarth (1911, 1912, 1924), and Brooks (1917, 1924) all indicated that adult female Black Swifts are indistinguishable from adult males. Marín and Stiles (1992) agreed with Drew (1882) and Brooks (1924), stating that fully adult birds show no sexual dimorphism.

Many observers have used the white tipping of the abdominal feathers and undertail coverts as a method of sexing and aging Black Swifts. Drew (1882), Swarth $(1911,1912)$, and Brooks (1917) stated that as the birds age, the white tips of the ventral feathers disappear completely. Rathbun (1925) concluded that there is a seasonal variation in the markings of the 
posterior underparts of females, with birds collected from early June to mid-July having progressively larger white tips on the abdominal feathers and undertail coverts, to the point they form circular spots. Davis (1931) related that three female specimens were flecked with white on breast and belly but one had no white tipping; he questioned whether this was due to the age of the birds or if there could be that much variation in birds in any one year. Ridgway (1911) stated that specimens with white-tipped feathers on posterior underparts are females and those without white-tipped feathers are males. Brooks (1924) and Rathbun (1925) reported that males lack any trace of light tipping on the ventral feathers and that the majority of females have the feathers of the lower breast and abdomen broadly edged with white. Zimmer (1945) concluded that male Black Swifts often show some trace of narrow pale tips on the ventral feathers. Marín and Stiles (1992) concluded from museum study skins that white tipping occurs in young Black Swifts at least into their second year. Later, also on the basis of museum specimens, Marín (1997) stated that white tipping on the abdomen and crissum persists for at least three years and possibly more. Neither Marín and Stiles (1992) nor Marín (1997) specified the sex of the specimens or indicated how their age was determined.

Some researchers have mentioned sexual dimorphism in the depth of the tail fork, expressed as the difference between the length of the outermost rectrix ( $\mathrm{r} 5$ ) and the innermost rectrix ( $\mathrm{r} 1$ ). Drew (1882) stated that as birds progress from young of the year to their fourth year, their tail changes from rounded to forked, but he did not describe how he aged the birds. Brooks (1917) stated that females aged two years and over have a forked tail. Swarth (1911, 1912) and Zimmer (1945) noted that males have a deeply forked tail and females have a square or slightly rounded tail, except for one specimen of a male with a distinctly rounded tail, a characteristic Zimmer attributed to age of the bird. M. A. Marín (pers. comm.) concluded that the degree of tail fork is related to age, not sex, and he stated that Pyle (1997) was incorrect in stating that females retain a squarish tail with a fork of no more than $3 \mathrm{~mm}$.

The long duration of our study, measurements of 181 swifts, genetic determination of sex, and statistical analysis of measurements clarifies previous misconceptions and accurately represents sexual dimorphism in the plumage of the Black Swift.

\section{METHODS AND STUDY AREAS}

We captured Black Swifts at four colonies in Colorado, one in New Mexico, and one in Idaho from 2004 through 2017 (Table 1).

We captured swifts with mist nets or hand-held nets (mesh of both 38 $\mathrm{mm}$ ) from the third week of July to the last week of August. These dates coincide with the third quarter of the breeding season (Hirshman et al. 2007). Because, during this part of the breeding season, swifts visit their nests infrequently during daytime, we attempted to capture them from 05:30 to 07:00 or 19:00 to 21:00 Mountain Daylight Time. Each individual was marked with a U.S. Geological Survey aluminum band. We took measurements as described by Pyle (1997), including wing length, length of outermost ( $\mathrm{r} 5$ ) and innermost $(r 1)$ rectrices to the nearest millimeter, and body weight to the 
nearest tenth of a gram. We quantified the white tipping on the abdomen and undertail coverts as the longest white tip on these feathers, measured to the nearest $0.5 \mathrm{~mm}$. To track any changes in white tipping over time, we photographed the birds' underparts.

Ten individual banders participated; $67 \%$ of birds were banded by Potter, $31 \%$ by Beason, and $16 \%$ by eight other persons. All banders were experienced, holding required federal and state banding permits, which helped minimize variation in measurements among banders. In some cases, more than one bander handled birds at a colony during a year; in some cases, banders at a colony varied from one year to the next.

We do not address the other two recognized subspecies of the Black Swift, C. n. costaricensis and C. n. niger. Nor do we discuss the juvenal plumage, as it has been well described (Foerster 1987, Collins and Foerster 1995, Marín 1997, Pyle 1997) and is not useful for identifying sex.

For sexing of all the swifts we handled, we collected blood and/or feathers and submitted them to one of two laboratories. The U.S. Geological Survey's FORT Molecular Ecology Laboratory, Ft. Collins, Colorado, received 71 samples. At this laboratory, DNA was isolated from blood or feather samples and was amplified at two loci developed for sexing of birds: P8/P2 (Griffiths et al. 1998) and Z37B (Dawson et al. 2015). An individual was identified as female if the sample yielded two peaks at both of the loci and male if only one peak was observed at each locus. DDC Veterinary, Fairfield, Ohio, received 26 samples and also used the method of sex determination described by Griffiths et al. (1998). Twenty-five samples were sent to both labs. All blood and feather samples amplified, we did not detect any errors in sex determination, and results from the two labs matched $100 \%$ of the time.

We evaluated the distributions of eight variables to identify overt differences between the sexes. Candidate covariates included wing chord, flat wing, $r 5$ length, $r 1$ length, the difference between $r 5$ and $r 1$, length of white tipping on the abdomen and undertail coverts, and body weight. Difference in length of rectrices alone accounted for over $99 \%$ of the variance between the sexes and minimized cases of missing data. We therefore used this variable in a discriminant analysis function (Dechaume-Moncharmont et al. 2011) to assess its ability to differentiate between male and female Black Swifts. We used three validation methods to assess the accuracy of the discriminant function in classifying individuals: resubstitution, jack-knife cross-validation, and splitting the dataset into two subsets, a training subset consisting of two-thirds of the birds measured and a testing subset consisting

Table 1 Sites of Captures of Black Swifts Measured in This Study

\begin{tabular}{lcc}
\hline Study site & Coordinates & Elevation \\
\hline Fulton Resurgence Cave, Colorado & $39^{\circ} 49^{\prime} \mathrm{N}, 107^{\circ} 24^{\prime} \mathrm{W}$ & $3015 \mathrm{~m}$ \\
Box Canyon Falls, Colorado & $38^{\circ} 1^{\prime} \mathrm{N}, 107^{\circ} 40^{\prime} \mathrm{W}$ & $2377 \mathrm{~m}$ \\
Zapata Falls, Colorado & $37^{\circ} 37^{\prime} \mathrm{N}, 105^{\circ} 33^{\prime} \mathrm{W}$ & $2869 \mathrm{~m}$ \\
St. Charles River Falls, Colorado & $37^{\circ} 59^{\prime} \mathrm{N} ; 105^{\circ} 0^{\prime} \mathrm{W}$ & $2320 \mathrm{~m}$ \\
Jemez Falls, New Mexico & $35^{\circ} 48^{\prime} \mathrm{N}, 106^{\circ} 36^{\prime} \mathrm{W}$ & $2377 \mathrm{~m}$ \\
Shadow Falls, Idaho & $47^{\circ} 45^{\prime} \mathrm{N}, 116^{\circ} 6^{\prime} \mathrm{W}$ & $1058 \mathrm{~m}$ \\
\hline
\end{tabular}


of the other third. The training subset served as the basis of predictions for the testing subset (Dechaume-Moncharmont et al. 2011).

We did not have a sample of repeatedly measured individuals sufficient for evaluating changes in the variables over time directly. However, the relative richness of the dataset in terms of total number of individuals captured over many years allowed us to leverage repeated subsampling within each year to calculate the mean of four of the variables (wing chord, depth of tail fork, abdominal white tipping, and undertail covert white tipping). We calculated the mean of a sample of five individuals from each of the 12 years (for a total sample across years of 60) by sex and for each metric, and repeated this process 100,000 times to arrive at a distribution of subsampled population means through time. This procedure accounts for varying representation of the available population in any given year's crop of captured individuals (e.g., one year the random sampling may overrepresent older individuals, while the next year the random sampling may overrepresent younger individuals).

\section{RESULTS}

We banded 34 adult males and 38 adult females. Of those, 17 males (49 total recaptures) and 24 females (60 total recaptures) were recaptured from one through 13 years later, some swifts being recaptured multiple times, for a total of 181 captures. For the discriminant function analysis, we included only a single observation per individual (72 observations). Table 2 lists results of the eight measurements obtained for both males and females when the birds were first banded. Some weights included boluses of insects in the swift's esophagus; boluses can range up to $3.8 \mathrm{~g}$ in wet weight (Potter unpubl. data).

Figure 1 shows results for males versus females for each of the eight variables measured. With the difference in length of rectrices between sexes as the sole predictor, the resubstitution method for validation yielded a classification accuracy of $95.88 \%$ (95\% confidence interval $[\mathrm{CI}]=95.84 \%-95.92 \%)$. Jack-knife cross-validation yielded a classification accuracy of $95.21 \%$ (95\% $\mathrm{CI}=95.16 \%-95.26 \%)$. Splitting the dataset produced a classification accuracy of $95.75 \%(95 \% \mathrm{CI}=95.73 \%-95.78 \%)$.

Table 2 Mean Measurements (mm) and Weights (g) of Adult Black Swifts

\begin{tabular}{lcc}
\hline Sex & Male & Female \\
\hline Wing chord & $165.8(160-173$, & $163.4(156-170$, \\
Flat wing & $n=34,3.1)$ & $n=38,3.6)$ \\
& $170.1(160-179$, & $168.6(163-173$, \\
r5 & $n=18,4.3)$ & $n=20,2.9)$ \\
r1 & $57.9(51-65, n=34,3.3)$ & $50.6(36-55, n=38,3.2)$ \\
r5 minus r1 & $51.4(46-57, n=34,2.8)$ & $49.6(36-54, n=38,3.1)$ \\
Abdominal tipping & $6.5(1-9, n=34,2)$ & $0.9(0-3, n=38,0.9)$ \\
Undertail covert tipping & $0.5(0-2.8, n=20,0.8)$ & $2.7(0-4.6, n=23,1.3)$ \\
Weight & $45.6(39.3-50.1$, & $1.0(0-2.9, n=23,0.7)$ \\
& $n=34,2.8)$ & $44.0(37.7-49.4$, \\
& & $n=36,3.5)$ \\
\hline
\end{tabular}

${ }^{a}$ Ranges, sample size, and standard deviation in parentheses. 


\section{SEXUALLY DIMORPHIC PLUMAGE IN THE NORTHERN BLACK SWIFT}
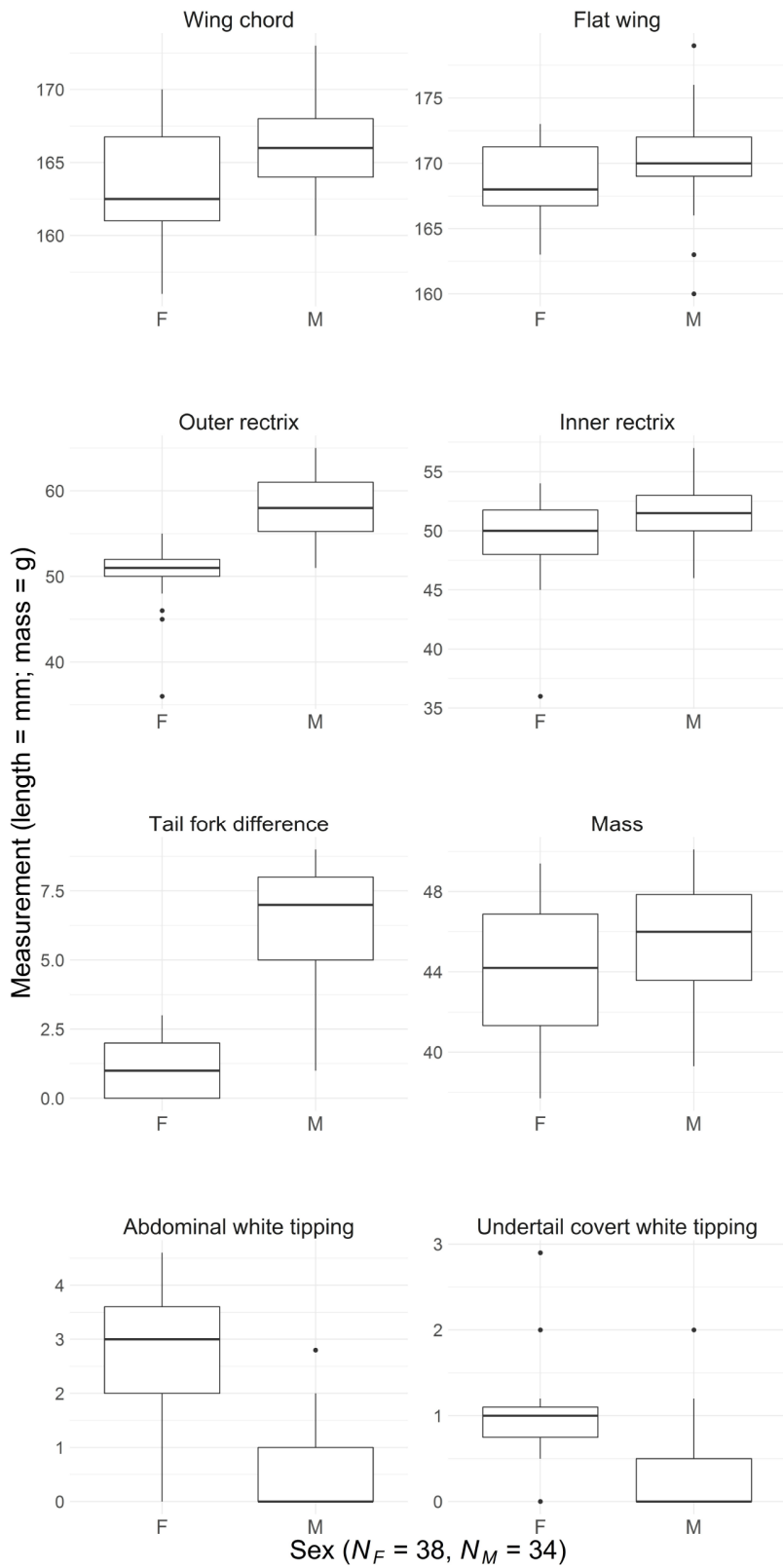

Figure 1. Box plots for the eight variables measured that could serve as predictors of sex in the Black Swift. Heavy horizontal line, median; box, $25 \%$ and $75 \%$ quantiles; whiskers, $5 \%$ and $95 \%$ quantiles; dots, outliers. 
With the exception of three males among the 72 birds sampled, we found no overlap in tail-fork depth ( $\mathrm{r} 5$ minus $\mathrm{r} 1$ ) between the sexes, as assessed by DNA analysis (Figure 2). There was a clear threshold around 2-3 mm distinguishing males and females by depth of tail fork.

Nevertheless, one male (sex determined genetically by two different labs) captured eight times over a 10-year period had an average tail-fork measurement of $2.9 \mathrm{~mm}$ (range 2-4 mm), within the range reported for females by Pyle (1997).

We found the length of white tipping of the abdominal feathers to be $82 \%$ greater and that of the undertail coverts to be $70 \%$ greater in females than in males (Table 2, Figure 1), but this metric alone was not a conclusive predictor of sex. Some females completely lacked white tipping, and some males had a slight degree of white tipping.

The number individuals we captured repeatedly was not large, but we used the data on the change in values of each metric in recaptured individuals over time as a rough validation of our population-level approach. Since we saw no substantive variation over time in any measurement, either at the population level or in the individuals that were recaptured, we are confident that these attributes are relatively immutable throughout an individual's life (Figure 3 ). Given the variation in the measurements at both the population and individual level from year to year, we infer a high degree of sampling error, in spite of all banders being highly experienced and well trained (Figure 4).

The presence or absence of white tipping on the abdomen and undertail

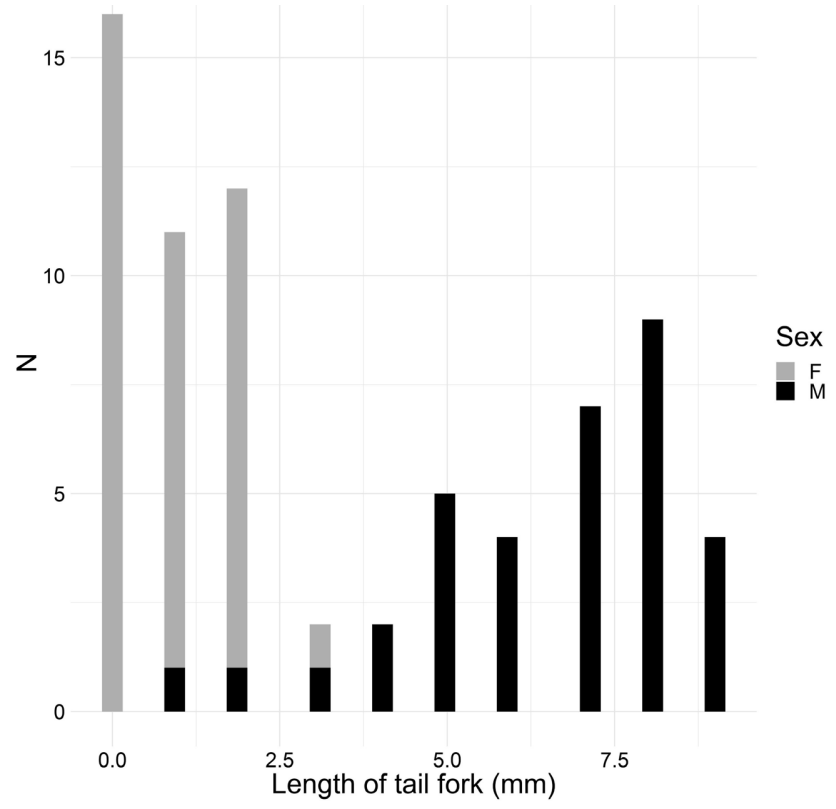

Figure 2. Depth of tail fork length ( $r 5$ minus $r 1$ ) by sex in 72 Black Swifts with data on this measure. 
coverts of an individual remained relatively constant through time irrespective of its sex or age. Figures 5-7 are representative photographs of this finding.

\section{DISCUSSION}

The large number of observations in our study, its long duration, genetic sex determination, and statistical analysis of the data have clarified misinterpretations about sexual dimorphism in the Northern Black Swift. The difference in the lengths of the outer and inner rectrices is an easy, repeatable, and nearly conclusive measurement for sexing the species.

Because the difference in the length of rectrices alone accounted for over 99\% of the variance between the sexes, we did not include other variables in the statistical analysis. Additional variables weakened the distinguishability of the sexes because more individuals had to be excluded from evaluation as a result of missing data. For instance, only 10 individuals lacked data on tail-fork depth, while 50 individuals lacked data on the extent of white on the abdomen. Only 19 individuals had data for every variable.

Our measurements of wing length, tail length, and tail-fork depth agree with a few previous reports (Kennerly 1857, Zimmer 1945, Pyle 1997). However, our study did not corroborate other published statements about the Black Swift's plumage variation by age or sex that were based on small sample sizes without individuals being followed through time (Drew 1882, Swarth 1911, 1912, 1924; Brooks 1917, Rathbun 1925, Davis 1931, Marín and Stiles 1992, M. A. Marín pers. comm.). Early descriptions by Baird (1858), Elliot (1869), Cooper (1870), and Coues (1872) only reiterated Kennerly's (1857) observations of one male Black Swift, stating that the tail is forked, the tips of undertail coverts are gray, and the wing is about $171 \mathrm{~mm}$ long.

Little is known about the molt of the Northern Black Swift. In our study, no adult birds showed loss of any flight feathers, retained flight feathers, or distinct molt limits during the latter part of the breeding season. Swarth (1922) reported that 17 swifts collected at Sergief Island, Alaska, 12 June 1919, had finished the annual molt and were in new plumage. Rathbun (1925) collected 31 birds from late June to early August in Washington and stated that the plumage seemed to have been recently renewed, being bright with no traces of molt. Pyle (1997) stated that in their year of hatching, Black Swifts are believed to undergo their first prebasic molt from July to November. However, no hatch-year swifts that we handled from July through August showed signs of molt prior to fledging. Black Swifts are presumed to begin their southward migration immediately upon fledging. From examination of specimens, Pyle (1995) concluded that in both first-year and adult Black Swifts the prebasic molt of flight feathers likely takes place in the winter range and is complete but protracted. Most body feathers are replaced by January, and replacement of flight feathers extends through the winter and early spring. Howell (2010) generally agreed with Pyle, predicting that Black Swifts do not molt in North America, and that the prebasic molt occurs in the nonbreeding range.

Body mass is probably least helpful in determining sex in the Northern Black Swift. Presence of an insect bolus can increase body weight. The condition of the bird and the season in which it is captured add additional variation 


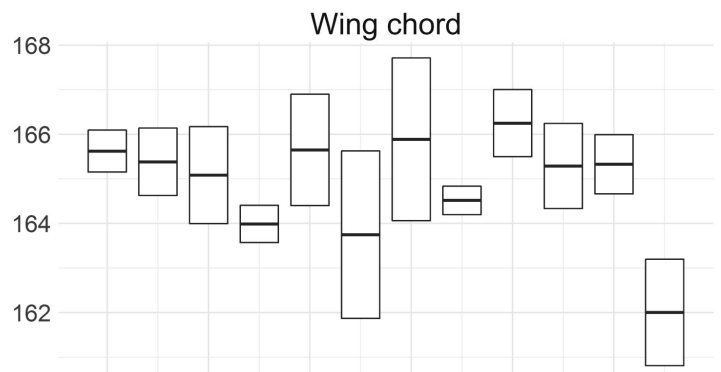

Tail fork difference

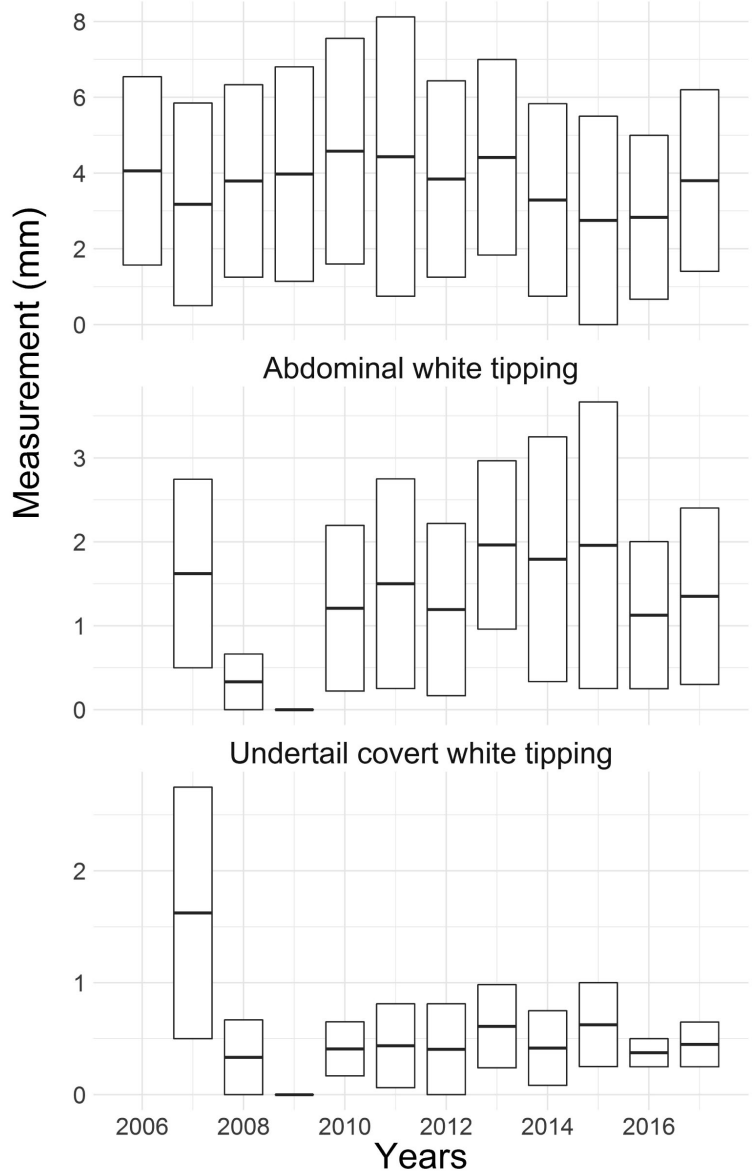

Figure 3. Box plots by year for four variables measured in the Black Swift. Year-to-year variation in values is likely driven by variation in banders' measurement techniques, less so by changes in individual birds, a conclusion supported by results displayed in Figure 4. 

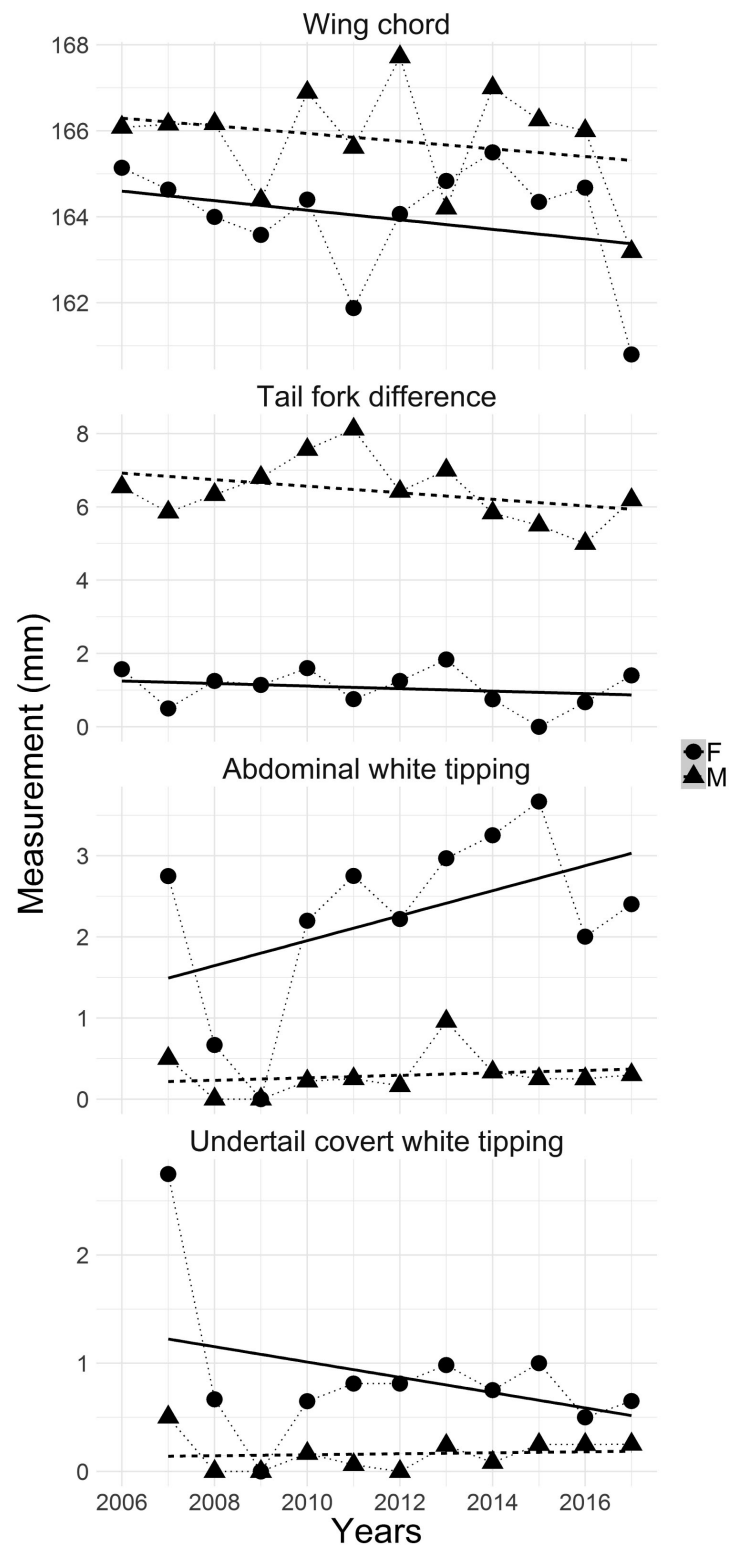

Figure 4. Trends of change over time for four variables in Black Swifts captured repeatedly, by sex. Lines represent linear regression for each sex (slopes near zero suggest no change over time). Only the extent abdominal white tipping among females demonstrated any substantive change over time (slope 0.153). All other slopes were less than 0.1 units from zero. 


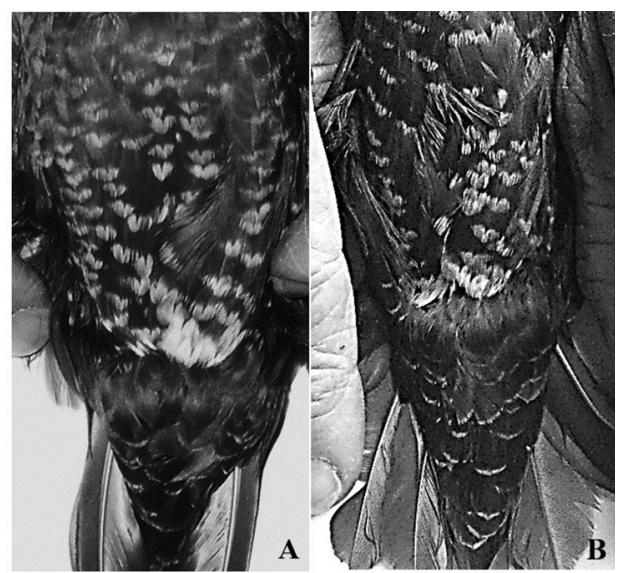

Figure 5. (A) Female Black Swift banded 28 August 2006 at an age of $\geq 1$ year and photographed at Fulton Resurgence Cave 21 July 2010; length of white tips on the abdominal feathers and undertail coverts recorded as $5 \mathrm{~mm}$ and $1 \mathrm{~mm}$, respectively. (B) Same individual photographed 29 August 2017; length of white tips on the abdominal feathers and undertail coverts recorded as $4 \mathrm{~mm}$ and $0.5 \mathrm{~mm}$, respectively. The characteristics were essentially unchanged over a period of eight years, until the swift was at least 12 years of age.

to this metric. There is no published information on clinal variation in size in C. $n$. borealis, so it is unknown whether body mass varies geographically.

The maximum longevity reported for the Northern Black Swift is 16 years, 1 month (Lowther and Collins 2002). This protracted life span al-

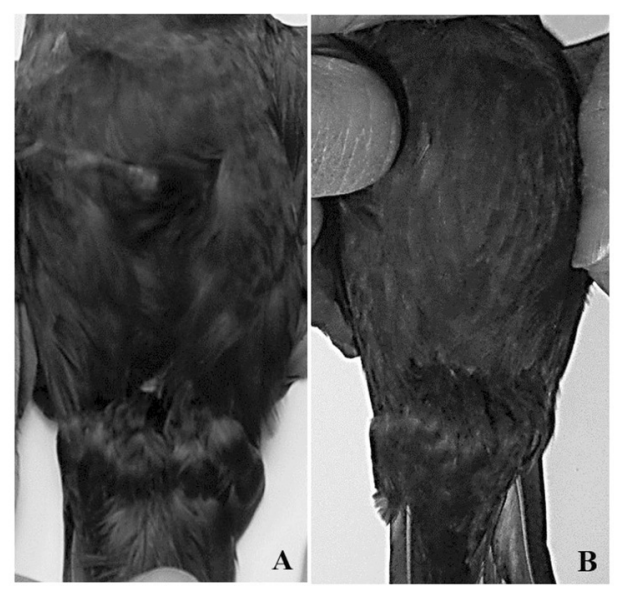

Figure 6. (A) Female Black Swift banded 25 August 2008 at an age of $\geq 1$ year and photographed at Fulton Resurgence Cave 22 August 2011; no white tips on either abdominal feathers or undertail coverts. (B) Same individual photographed 24 August 2016; no change over six years, until the swift was at least nine years of age. 


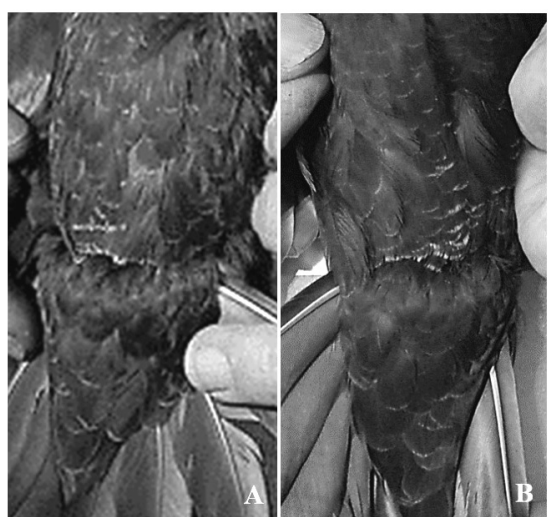

Figure 7. (A) Male Black Swift banded and photographed at Fulton Resurgence Cave 21 July 2010 at an age of $\geq 2$ years; length of white tips on the abdominal feathers and undertail coverts recorded as $1 \mathrm{~mm}$ and $0.5 \mathrm{~mm}$, respectively. (B) Same individual photographed on 26 August 2014; no change over five years, until the swift was at least seven years of age.

lows for further sampling and broader verification of the results of our study. Examination of other characteristics such as a brood patch and cloacal protuberance early in the breeding season may confirm the sex of a breeding Black Swift.

\section{ACKNOWLEDGMENTS}

The Denver Field Ornithologists Research, Education and Conservation Fund, the Colorado Field Ornithologists, the Colorado Chapter of the Wildlife Society, and Phil Steer helped support costs for DNA analysis. We are indebted to Sara Oyler-McCance and Jennifer Fike for sexing the swifts on the basis of our samples. Brett Walker and Reesa Conrey kindly provided early reviews and helpful comments on the manuscript. Charles Collins and Peter Lowther formally reviewed the manuscript and provided invaluable feedback. The Rifle Ranger District, White River National Forest, provided generous in-kind support of this project.

\section{LITERATURE CITED}

Baird, S. F. 1858. Reports of Explorations and Surveys to Ascertain the Most Practicable and Economical Route for a Railroad from the Mississippi River to the Pacific Ocean, vol. IX. Beverly Tucker, Washington, D.C.

Brooks, A. 1917. Birds of the Chilliwack District, B.C. Auk 34:28-50; doi $10.2307 / 4072537$.

Brooks, A. 1924. Sexual variation in Nephoecetes niger. Auk 41:383; doi $10.2307 / 4074678$.

Collins, C. T., and Foerster, K. S. 1995. Nest site fidelity and adult longevity in the Black Swift (Cypseloides niger). N. Am. Bird Bander 20:11-14.

Cooper, J. G. 1870. Ornithology of California. Land Birds (S. F. Baird, ed.), vol. 1. Welch, Bigelow, and Company Univ. Press, Cambridge, MA. 
Coues, E. 1872. Key to North American Birds. Naturalists' Agency, Salem, MA; doi $10.2307 / 4074678$.

Davis, W. B. 1931. Black Swift notes. Murrelet 12:24.

Dawson, D. A., Brekke, P., dos Remedios, N., and Horsburgh, G. J. 2015. A marker suitable for sex-typing birds from degraded samples. Cons. Genet. Resour. 7:337-343; doi 10.1007/s12686-015-0429-3.

Dechaume-Moncharmont, F. X., Monceau, K., and Cezilly, F. 2011. Sexing birds using discriminant function analysis: A critical appraisal. Auk 128:78-86; doi 10.1525/auk.2011.10129.

Drew, F. M. 1882. Notes on the plumage of Nephoecetes niger borealis. Bull. Nuttall Ornithol. Club 7:182-183.

Elliot, D. G. 1869. Birds of North America, vol. 1. D. G. Elliot, New York.

Foerster, K. S. 1987. The distribution and breeding biology of the Black Swift (Cypseloides niger) in southern California. M. S. thesis, Calif. State Univ., Long Beach.

Griffiths, R., Double, M. C., Orr, K., and Dawson, R. J. G. 1998. A DNA test to sex most birds. Molec. Ecol. 7:1071-1075; doi 10.1046/j.1365294x.1998.00389.x.

Hirshman, S. E., Gunn, C., and Levad, R. G. 2007. Breeding phenology and success of Black Swifts in Box Canyon, Ouray, Colorado. Wilson J. Ornithol. 119:678-685; doi 10.1676/06-112.1.

Howell, S. N. G. 2010. Molt in North American Birds. Houghton Mifflin Harcourt, New York.

Kennerly, C. B. R. 1857. Description of a new species of Cypselus, collected on the North Western Boundary Survey, Archibald Campbell, Esq., Commissioner. Proc. Acad. Nat. Sci. Philadelphia 9:202-203.

Lowther, P. E., and Collins, C. T. 2002. Black Swift (Cypseloides niger), in The Birds of North America (A. Poole and F. Gill, eds.), no. 676. Birds N. Am., Philadelphia; doi 10.2173/bna.676.

Marín, M. A. 1997. Some aspects of the breeding biology of the Black Swift. Wilson Bull. 109:290-306.

Marín, M. A., and Stiles, F. G. 1992. On the biology of five species of swifts (Apodidae, Cypseloidinae) in Costa Rica. Proc. W. Found. Vert. Zool. 4:387-351.

Pyle, P. 1995. Incomplete flight feather molt and age in certain North American non-passerines. N. Am. Bird Bander 20:15-26.

Pyle, P. 1997. Identification Guide to North American Birds, part 1. Slate Creek Press, Bolinas, CA.

Rathbun, S. F. 1925. The Black Swift and its habits. Auk 42:497-516; doi $10.2307 / 4074986$.

Ridgway, R. 1911. Birds of North and Middle America. Bull. U. S. Nat. Mus. 50, part V. Government Printing Office, Washington, DC.

Swarth, H. S. 1911. Birds and mammals of the 1909 Alexander Alaska Expedition. Univ. Calif. Publ. Zool. 7:9-172.

Swarth, H. S. 1912. Differences due to sex in the Black Swift. Auk 29:241-242; doi $10.2307 / 4071379$.

Swarth, H. S. 1922. Birds and mammals of the Stikine River region of northern British Columbia and southeastern Alaska. Univ. Calif. Publ. Zool. 24:125-314; doi 10.5962/bhl.title.121745.

Swarth, H. S. 1924. Sexual variation in Nephoecetes niger. Auk 41:383-384; doi $10.2307 / 4074678$.

Zimmer, J. T. 1945. A new swift from Central and South America. Auk 62:586-592; doi $10.2307 / 4079809$. 